\title{
IN MEMORY OF Professor Ferenc GÉCSEG
}

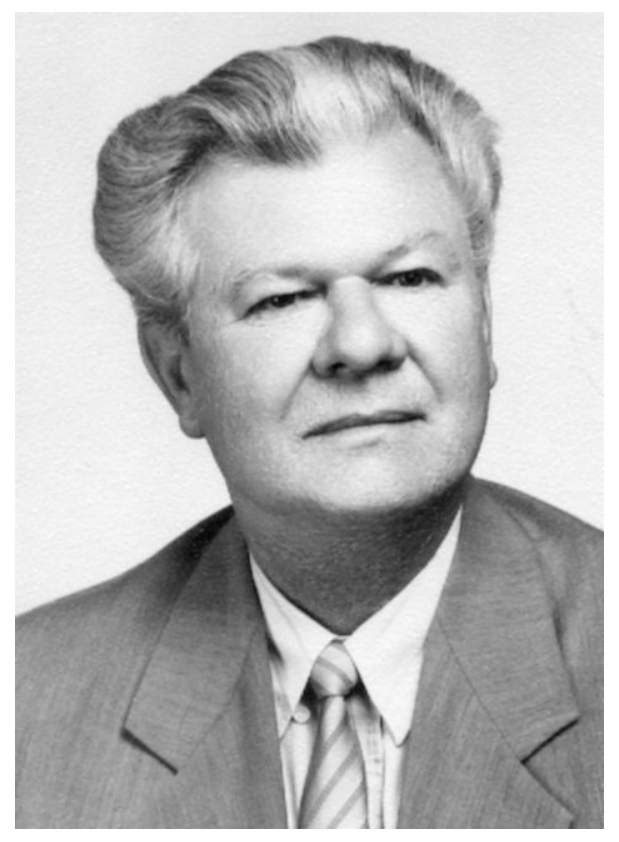



Professor Ferenc Gécseg, member of the Hungarian Academy of Sciences and Professor Emeritus of the University of Szeged, passed away on 6th October, 2014.

Professor Gécseg studied at the József Attila University from 1957 to 1962 and received his master degree as mathematics teacher for secondary schools, specialising in algebra. He joined the faculty of the University of Szeged (or Attila József University as it was called at that time) in 1962 and worked at this university for his entire career. In 1976 he received the degree of Doctor of Mathematical Sciences of the Hungarian Academy of Sciences and was promoted to full professor in 1977. For several years, he was the chair of the Department of Computer Science of the Institute of Mathematics and the head of the Research Group on Theory of Automata of the Hungarian Academy of Sciences. Later he worked as full professor at the Department of Computer Algorithms and Artificial Intelligence of the Institute of Informatics. He was a founding member of the Doctoral School of Informatics.

At the beginning of his career, Professor Gécseg conducted research in universal algebra and later turned to the study of a basic algebraic model of computation, the so-called finite automaton. He obtained several results opening new vistas in the field of describing the behaviour of finite automata and systems of finite automata. His results concerning the composition and decomposition of automata play an important role, among others, in the study of the complexity of digital networks. At the end of the 1970's, he became interested in tree automata and tree transducers. He co-authored the first monograph dealing with tree automata. Since tree transducers are a mathematical model of syntax directed translation, his studies in this area are also relevant to the theory of machine translation. Professor Gécseg published three monographs, a book chapter, a textbook, and over eighty academic articles in leading periodicals and refereed conference proceedings.

He was the main organiser of the conferences 'Algebraic Theory of Automata' in the mid 1970's in Szeged which at that time played an important role in creating and maintaining connections between the scientists of our region and those of the western countries. Thanks to his teaching and research activities, an automata theory school evolved in Szeged. Several of his former students are now leading tutors and professors with extensive international contacts and quite a few of them were Széchenyi Professor Scholarship holders. A number of scientists have joined his research work both in Hungary and abroad, the number of citations for his publications is over 1000. In recognition of his academic work, he was elected corresponding member of the Hungarian Academy of Sciences in 1987, foreign member of the Finnish Academy of Sciences in 1994, and full member of the Hungarian Academy of Sciences in 1995. In 1989, he became vice-president of the European Association for Theoretical Computer Science and was reelected for another five years in 1994. He was a member of the editorial board of foreign and Hungarian periodicals and served as the editor in chief of the journal Acta Cybernetica for about two decades. He was regularly invited to programme committees of international conferences and acted as the chairman of the programme committees of FCT 
81, FCT 89 and ICALP 95, which is one of the most highly ranked international conferences in theoretical computer science. These conferences were all organised in Szeged.

On several occasions he spent quite some time at foreign universities. He was a visiting professor for a year at Turku University in 1973-74; spent six months at Tampere University of Technology in 1978 and six months at the University of Western Ontario in 1987. In 1992, he worked for six months in Turku as a research professor of the Finnish Academy of Sciences.

He actively participated in the university administration and the academic public life. He was the dean of the Faculty of Science of József Attila University from 1987 to 1990 . He served as a member of several ministerial and academic committees, including the Committee on Mathematics and the Committee on Information Science of the Hungarian Academy of Sciences.

Professor Gécseg played a decisive role in establishing a recognised degree programme in Informatics at the University of Szeged, in the creation of a school of fundamental research in the theory of automata in Hungary, and by raising it to international standing. At the same time, he did an exemplary work in teaching at our university and produced very high quality academic results.

His death is a great loss to the University of Szeged and the scientific community.

Szeged, September, 2015

Zoltán Ésik and Zoltán Fülöp 